Assessment of $\mathrm{MgHf}_{4} \mathrm{P}_{6} \mathrm{O}_{24}$ Electroceramic Oxide Electrolyte in High-Temperature Electrochemical Sensor for Sensing Mg in Non-Ferrous Alloys

Mohammed Adamu ${ }^{1 *}$ and Girish M Kale ${ }^{1}$

${ }^{1}$ School of Chemical and Process Engineering, University of Leeds, Leeds LS2 9JT, United Kingdom.

In this paper, the electrochemical impedance analysis of $\mathrm{MgHf}_{4} \mathrm{P}_{6} \mathrm{O}_{24}$ electroceramic oxide electrolyte on platinised pellets of $13 \mathrm{~mm}$ diameter $(\varnothing)$ and $3.8 \mathrm{~mm}$ thickness depicts the electrical properties of $\mathrm{Mg}^{2+}$-cation conducting species in the characterised solid-state electrolytes measured using the two-probe analysis at $182-764^{\circ} \mathrm{C}$, and from $100 \mathrm{mHz}$ to $32 \mathrm{MHz}$, were evaluated. In this analysis, promising ionic conductivity of $4.52 \times 10^{-4} \mathrm{Scm}^{-1}$ for $\mathrm{MgHf}_{4} \mathrm{P}_{6} \mathrm{O}_{24}$ electroceramic electrolyte was exhibited at $747^{\circ} \mathrm{C}$, thereby maintaining both materials and operational stability at $1000^{\circ} \mathrm{C} \leq \mathrm{T} /{ }^{\circ} \mathrm{C} \leq 1300$.

In addition to this, the design, fabrication and testing of solid-state $\mathrm{Mg}$-sensors using the electrochemical method have been achieved. The novel high-temperature Mg-sensors were designed using the highly conducting $\mathrm{Mg}^{2+}$-cation solid-state electrolyte by incorporating a biphasic powder mixture of $\mathrm{MgCr}_{2} \mathrm{O}_{4}+\mathrm{Cr}_{2} \mathrm{O}_{3}$ as ceramic solid-state reference electrode in air, which has shown promising trend after successfully sensing the $\mathrm{Mg}$ dissolved in molten $\mathrm{Al}$ at $700 \pm 5^{\circ} \mathrm{C}$. A linear dependence of emf on logarithm of $\mathrm{Mg}$ concentration was achieved. The transport number, $\mathrm{t}_{\mathrm{mg} 2+}=0.84 \pm 0.03$ was achieved which indicates that the conducting specie in $\mathrm{MgHf}_{4} \mathrm{P}_{6} \mathrm{O}_{24}$ solid-state electrolyte is $\mathrm{Mg}^{2+}$-cation. The solid-state electrolyte has the potential for application in high-temperature electrochemical sensors and other devices.

Introduction

Electroceramics such as magnesium zirconium phosphate and other phosphate solid-state electrolytes have been widely studied owing to their potential as solid electrolyte in electrochemical devices and thermodynamic measurements [1-7].

Recently, extensive attention has been assigned to the synthesis and characterisation of magnesium zirconium phosphate, $\mathrm{MgZr}_{4} \mathrm{P}_{6} \mathrm{O}_{24}$, owing to their compositions and wide applications as ionic conductor in electrochemical devices. The various methods assigned to the synthesis of $\mathrm{MgZr}_{4} \mathrm{P}_{6} \mathrm{O}_{24}$, such as solid-state method, sol-gel method, and hydrothermal method have yielded electrolytes with varied ionic conductivity.

The various intensive research interest in materials synthesis and characterisation however shows the benefit of knowing the behaviour of materials in operation. Today, various materials function in both ambient and high temperature environment, as such, appropriate materials are selected for certain application. Selecting materials for high temperature application requires operational stability of relevant materials properties as well as environmental suitability compared to applications at ambient temperatures. Temperature influences the stability of functional materials in operation and the need to select materials suitable for different application is needed. $\mathrm{Mg}^{2+}$-cation conducting behaviour of $\mathrm{MgZr}_{4} \mathrm{P}_{6} \mathrm{O}_{24}$ solid-state electrolyte is believed to depend on the sol-gel synthesis technique [1,2], it shows potential advantage of better homogeneity, better compositional control and lower processing temperature over the 
conventional solid-state method, which in this case accounts for a high percentage-relative density of the sintered sample pellets in ionic conductivity $[1,8]$. Recently, we reported the $\mathrm{Mg}^{2+}$-ion conducting behaviour of $\mathrm{MgZr}_{4} \mathrm{P}_{6} \mathrm{O}_{24}$ solid-state electrolyte prepared using the solgel chemical synthesis method [1], with potential application as solid electrolyte in hightemperature electrochemical sensors and thermodynamic measurements.

In this study however, the ionic conductivity of $\mathrm{MgHf}_{4} \mathrm{P}_{6} \mathrm{O}_{24}$ solid-state electrolyte was measured, and the design and fabricating of $\mathrm{Mg}$-sensor probes using $\mathrm{MgHf}_{4} \mathrm{P}_{6} \mathrm{O}_{24}$ as solidstate electrolyte and a biphasic powder mixture of $\mathrm{MgCr}_{2} \mathrm{O}_{4}+\mathrm{Cr}_{2} \mathrm{O}_{3}$ as the reference electrode. The excellent ionic conductivity data of $\mathrm{MgHf}_{4} \mathrm{P}_{6} \mathrm{O}_{24}$ solid-state electrolytes motivated the design and fabrication of solid-state Mg-sensors. In this study however, we report for the first time design and fabrication of novel high-temperature $\mathrm{Mg}$-senor probes using the novel $\mathrm{MgHf}_{4} \mathrm{P}_{6} \mathrm{O}_{24}$ solid-state electrolyte as $\mathrm{Mg}^{2+}$-cation conductor. Sensing $\mathrm{Mg}$ in molten $\mathrm{Al}$ at $700 \pm 5^{\circ} \mathrm{C}$ was achieved by varying the $\mathrm{Mg}$ composition in molten $\mathrm{Al}$, by alloying with 0.005 1.5 wt. $\% \mathrm{Mg}$. A biphasic powder equimolar mixture of $\mathrm{MgCr}_{2} \mathrm{O}_{4}+\mathrm{Cr}_{2} \mathrm{O}_{3}$ open to ambient $\mathrm{P}_{\mathrm{O} 2}$ was used as $\mathrm{Mg}$ reference electrode in designing and fabricating the electrochemical $\mathrm{Mg}$ sensors.

Materials and methods

\section{Preparation and characterisation}

All chemicals are analytical grade and used as received without further purification. Pure single phase $\mathrm{MgHf}_{4} \mathrm{P}_{6} \mathrm{O}_{24}$ solid-state electrolytes were synthesised using sol-gel method to produce very fine powders; this is achieved through mixing on an atomic scale by combining aqueous solutions of soluble salts at a relatively low crystallisation temperature and, it produces compositions not always possible by solid-state fusion method. The stoichiometric amount of pure chemical solutions made from precursors; $\mathrm{Mg}\left(\mathrm{NO}_{3}\right)_{2}, \mathrm{HfCl}_{4}$ and $\mathrm{NH}_{4} \mathrm{H}_{2} \mathrm{PO}_{4}$, in aqueous form were mixed separately in adequate proportion for the synthesis of $\mathrm{MgHf}_{4} \mathrm{P}_{6} \mathrm{O}_{24}$ solid-state electrolytes. The resulting dried xerogel powders were calcined at $900^{\circ} \mathrm{C}$, pelletised and then sintered at $1300^{\circ} \mathrm{C}$. The sintered pellets were characterised for their ionic conductivity and sensor evaluation. The electrochemical impedance spectroscopy measurement was achieved through the two-probe analysis method at $182-764^{\circ} \mathrm{C}$ temperature range, and from $100 \mathrm{mHz}$ to $32 \mathrm{MHz}$ frequency range.

\section{Electrochemical impedance characterisation}

For electrochemical impedance characterisation, the platinised pellets were prepared for impedance measurement by lightly grinding the two flat surfaces of the pellets sequentially on dried surfaces of silicon carbide ( $\mathrm{SiC}$ ) papers with grit size P400, P800, P1200, and P2500. Afterwards, geometric measurements on the sample pellets were achieved to determine the thickness and diameter of the solid-state electrolytes. Then, the sample pellets were platinised by applying platinum paste and cured at $800^{\circ} \mathrm{C}$ for $0.5 \mathrm{~h}$ in order to provide a good adhesion between platinum and solid-state electrolyte pellets and to also form contact electrode. The applied platinum provide good electrical contacts which also serves as a blocking electrode. The sample pellet was spring loaded in a quartz assembly rig placed inside a Faraday cage within horizontal Lenton LTF1200 tube furnace (Lenton Thermal Designs Ltd., Market 
Harborough, UK). A type-K thermocouple was inserted close to the sample pellet to subsequently monitor the actual temperature of the sample pellet at the point of impedance measurement. Furthermore, the actual temperature of the experiment was monitored and recorded through a plug and play temperature input device, the NI USB-TC01 to a LabVIEW interface (Business Park, Newbury, UK). The platinum wire clips were then connected to the Solartron SI1260 FRA impedance analyser which interfaced with a computer controlled by the software ZPlot (Scribner Associates, Inc. USA).

A schematic representation of the quartz assembly rig for impedance measurement is shown in Fig. 1. In this research however, the impedance analyser operates at a fixed applied voltage of $100 \mathrm{mV}$ and at an impedance furnace temperature range of $25 \leq \mathrm{T} /{ }^{\circ} \mathrm{C} \leq 800$. In order to monitor the reversibility properties of the sample pellets, a temperature variance of 50 to $100^{\circ} \mathrm{C}$ on decreasing and increasing temperature runs, respectively, depending on direction of measurements was applied. The impedance measurements were recorded after the measuring temperature had stabilised without temperature drift.

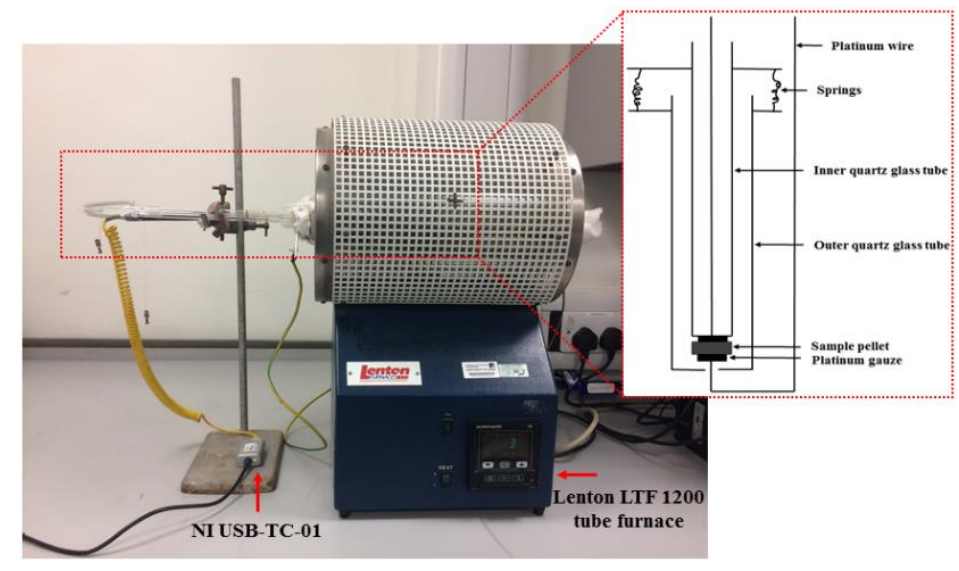

Figure 1. Quartz assembly rig for impedance measurements in a Lenton LTF 1200 tube furnace

\section{Sensor fabrication}

The potentiometric sensors for high-temperature solid-state $\mathrm{Mg}$-sensors characterised in this study for measuring concentration and determining the activity of $\mathrm{Mg}$ in liquid $\mathrm{Al}$ at $700 \pm 5^{\circ} \mathrm{C}$ were designed and fabricated using high conducting ceramic solid-state electrolytes, a nonreactive annealed $\mathrm{Fe}-\mathrm{Cr}$ alloy wire, Mo-rod counter electrode and a non-decomposing biphasic powder mixture of $\mathrm{MgCr}_{2} \mathrm{O}_{4}+\mathrm{Cr}_{2} \mathrm{O}_{3}$ reference electrodes. 


\section{Experimental setup}

Sample pellets of $\mathrm{MgHf}_{4} \mathrm{P}_{6} \mathrm{O}_{24}$ solid-state electrolytes was attached to an open end $50.8 \mathrm{~mm}$ long alumina tubes using pure alumina refractory cement (Parkinson-Spencer Refractories Ltd., Halifax, United Kingdom) to form simple alumina probes. A $0.25 \mathrm{~mm}$ thick annealed Fe$\mathrm{Cr}$ alloy wire (Goodfellow, Cambridge) was coiled, inserted and rammed down into the bottom of the alumina tube along with a biphasic powder mixture of $\mathrm{MgCr}_{2} \mathrm{O}_{4}+\mathrm{Cr}_{2} \mathrm{O}_{3}$ which served as reference electrodes. The respective solid-state $\mathrm{Mg}$-probes were extended by inserting them into a 120mm shock resistant SiAlON (Silicon Alumina Nitride) ceramic tubes, which were held firmly with alumina refractory cement to form bulk solid-state $\mathrm{Mg}$-sensors, respectively, as shown in Fig. 2.

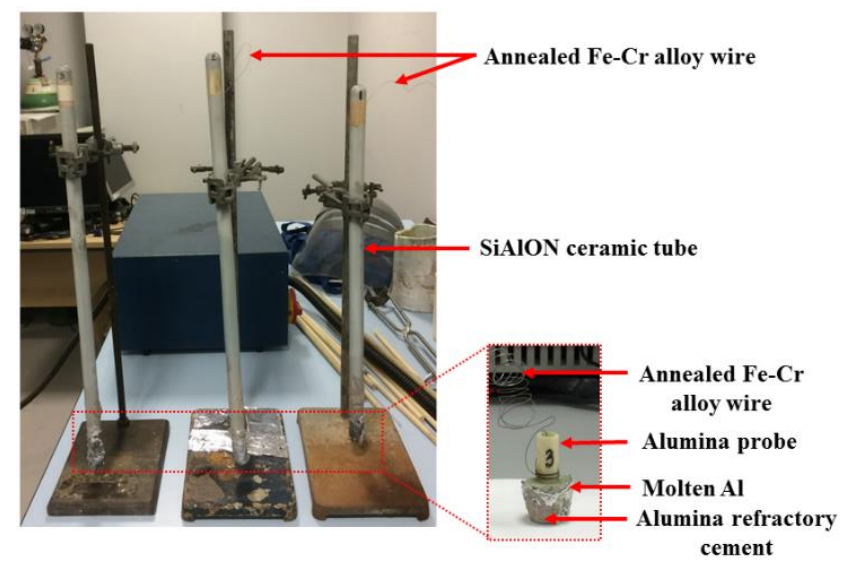

Figure 2. Solid-state Mg-sensors. Insert is a simple Mg-sensor before coupling

Results and discussions

Thermal analysis and phase identification

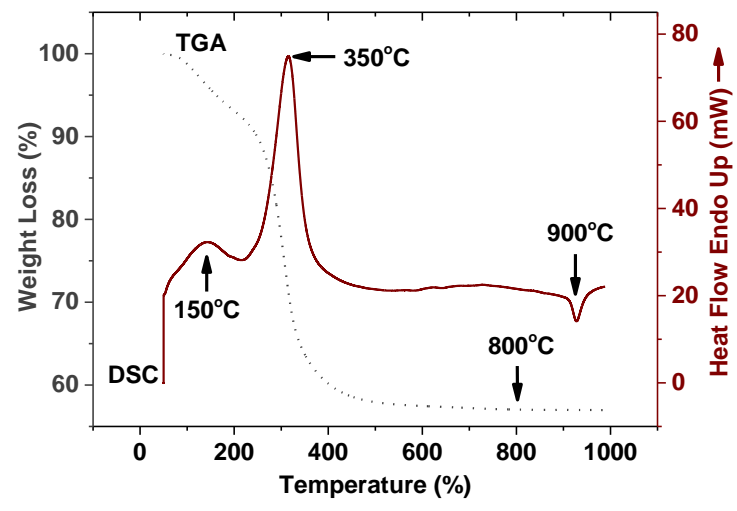

Figure 3. TGA-DSC curves of $\mathrm{MgHf}_{4} \mathrm{P}_{6} \mathrm{O}_{24}$ dried xerogel powders with scan rate of $10^{\circ} \mathrm{C} \mathrm{min}^{-}$ ${ }^{1}$ in the air. 
Thermal stability of the precursor xerogel of $\mathrm{MgHf}_{4} \mathrm{P}_{6} \mathrm{O}_{24}$ solid-state electrolyte was analysed using simultaneous TGA-DSC. The main decomposition changes in the TGA profiles in Fig. 3 is presented in three different regions. The first region within $30-100^{\circ} \mathrm{C}$ corresponds to the removal of lattice $\mathrm{H}_{2} \mathrm{O}$. The weight loss in a temperature region of $150-500^{\circ} \mathrm{C}$ is due to the decomposition or oxidation of gelled inorganic precursor materials such as $\mathrm{Mg}\left(\mathrm{NO}_{3}\right)_{2}, \mathrm{HfCl}_{4}$ and $\mathrm{NH}_{4} \mathrm{H}_{2} \mathrm{PO}_{4}$. There was no further reduction in weight above $500 \pm 25^{\circ} \mathrm{C}$ for $\mathrm{MgHf}_{4} \mathrm{P}_{6} \mathrm{O}_{24}$ xerogel powders. Similarly, the DSC profiles of $\mathrm{MgHf}_{4} \mathrm{P}_{6} \mathrm{O}_{24}$ xerogel powders in the same figure shows two endothermic decomposition peaks at $150^{\circ} \mathrm{C}$ and $350^{\circ} \mathrm{C}$, and an exothermic peak at $900^{\circ} \mathrm{C}$. The inorganic precursor, $\mathrm{NH}_{4} \mathrm{H}_{2} \mathrm{PO}_{4}$ decomposes into $\left(\mathrm{NH}_{4}\right)_{3} \mathrm{H}_{2} \mathrm{P}_{3} \mathrm{O}_{10}$ and $\mathrm{H}_{2} \mathrm{O}$ molecules at temperature range of $140-170^{\circ} \mathrm{C}$ which could be responsible for the endothermic peak at $150^{\circ} \mathrm{C} . \mathrm{Mg}\left(\mathrm{NO}_{3}\right)_{2}$ compound also decomposes into $\mathrm{MgO}, \mathrm{NO}_{2}$, and $\mathrm{O}_{2}$ at a temperature above $300^{\circ} \mathrm{C}$, this could be responsible for the endothermic peak at $350^{\circ} \mathrm{C}$. The reactive oxide $\mathrm{HfO}_{2}$ formed by the oxidation of $\mathrm{HfCl}_{4}$ at $432^{\circ} \mathrm{C}$ yields $\mathrm{MgHf}_{4} \mathrm{P}_{6} \mathrm{O}_{24}$ after stoichiometric reaction with $\mathrm{MgO}$ and $\mathrm{P}_{2} \mathrm{O}_{5}$ reactive oxides at $800^{\circ} \mathrm{C}-900^{\circ} \mathrm{C}$. Therefore, the exothermic peak observed at $900^{\circ} \mathrm{C}$ is for the formation of a single phase $\mathrm{MgHf}_{4} \mathrm{P}_{6} \mathrm{O}_{24}$ with full crystallinity. The single phase $\mathrm{MgHf}_{4} \mathrm{P}_{6} \mathrm{O}_{24}$ solid-state electrolyte started forming at $780^{\circ} \mathrm{C}$ as indicated on the TGA profile with absolute stability up to $900-1300^{\circ} \mathrm{C}$ range as was shown on the X-ray diffraction profile in Fig. 5. TGA-DSC measurements in this study was restricted to $1000^{\circ} \mathrm{C}$ because of the limitation of the equipment. Furthermore, it was noted that no further peak was observed on the DSC trace for $\mathrm{MgHf}_{4} \mathrm{P}_{6} \mathrm{O}_{24}$ precursor at higher temperatures.

\section{Relative density measurement}

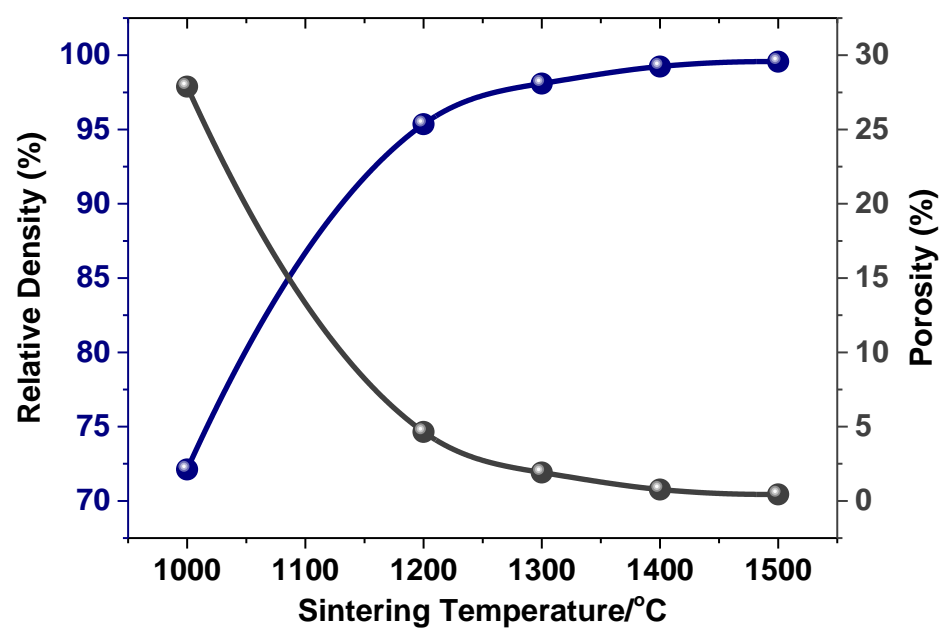

Figure 4. Dependence of percentage-relative density and porosity of the sample pellets of $\mathrm{MgHf}_{4} \mathrm{P}_{6} \mathrm{O}_{24}$ compound on sintering temperature

Solid-state $\mathrm{MgHf}_{4} \mathrm{P}_{6} \mathrm{O}_{24}$ sample pellet presented in Fig. 4 shows that relative density increases continuously with sintering temperature, from $1000^{\circ} \mathrm{C} \leq \mathrm{T} \leq 1500^{\circ} \mathrm{C}$, with $24 \mathrm{~h}$ of annealing time. In Fig. 4, the sample pellet begins to show some densification ( 95\%) at temperature higher than $1100^{\circ} \mathrm{C}$ and exhibit an optimum density of about $98 \%$ at $1300^{\circ} \mathrm{C}$ for $24 \mathrm{~h}$. Furthermore, the increment in density between $1300-1500^{\circ} \mathrm{C}$ is only $\sim 1 \%$, signifying that a 
saturation point has been reached for the densification of $\mathrm{MgHf}_{4} \mathrm{P}_{6} \mathrm{O}_{24}$ sample pellets. The porosity of $\sim 2 \%$ was achieved at $1300^{\circ} \mathrm{C}$ which is considered good enough for the solid-state electrolyte sample pellets in sensor application. In this research, $1300^{\circ} \mathrm{C}$ sintering temperature at annealing time of $24 \mathrm{~h}$ was considered suitable for purpose of comparison and that since the difference in percentage-relative density is only $\sim 1 \%$ from $1300-1500^{\circ} \mathrm{C}$, a saturation point was already achieved at $1300^{\circ} \mathrm{C}$. Using $1300^{\circ} \mathrm{C}$ as sintering temperature according to the density profile, a pure stable phase was also achieved for the characterised solid-state ceramic electrolytes.

Based on the thermal examination reported for $\mathrm{MgHf}_{4} \mathrm{P}_{6} \mathrm{O}_{24}$ dried xerogel powders in Fig. 3, single phase $\mathrm{MgHf}_{4} \mathrm{P}_{6} \mathrm{O}_{24}$ solid-state electrolyte was formed by calcining the dried xerogel powders at $800^{\circ} \mathrm{C}-900^{\circ} \mathrm{C}$. In addition, $1300^{\circ} \mathrm{C}$ was considered the sintering temperature of $\mathrm{MgHf}_{4} \mathrm{P}_{6} \mathrm{O}_{24}$ solid-state electrolyte observed in the relative density shown in Fig. 4. Therefore, formation of $\mathrm{MgHf}_{4} \mathrm{P}_{6} \mathrm{O}_{24}$ solid-state electrolyte presented in Fig. 5, shows single phase solidstate nanopowders calcined at $900^{\circ} \mathrm{C}$ and pellets sintered at $1300^{\circ} \mathrm{C}$, with the majority peaks matched and indexed accordingly.

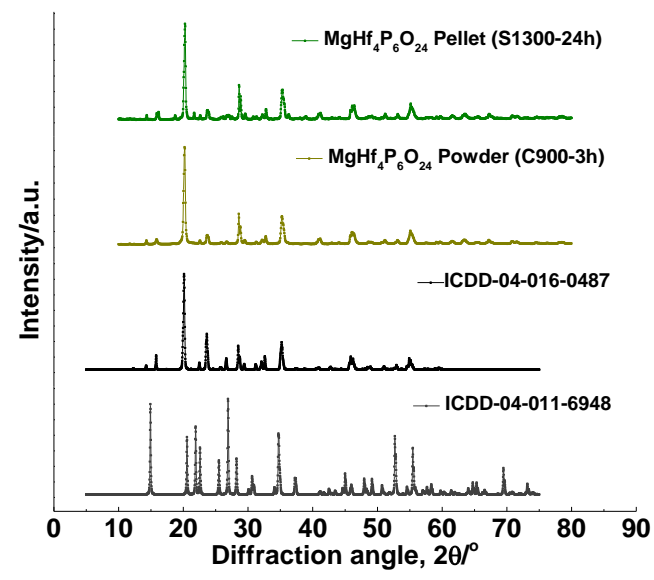

Figure 5. Combined XRD peak profiles of $\mathrm{MgHf}_{4} \mathrm{P}_{6} \mathrm{O}_{24}$ nanopowders calcined at $900^{\circ} \mathrm{C}$ and pellets sintered at $1300^{\circ} \mathrm{C}$, respectively. All peaks were indexed to $\mathrm{Mg}_{0.5} \mathrm{Zr}_{2}\left(\mathrm{PO}_{4}\right)_{3}$ [ICDD-04016-0487], and $\mathrm{Zr}_{2}\left(\mathrm{PO}_{4}\right)_{2} \mathrm{O}$ [ICDD-04-011-6948].

\section{Impedance analysis}

Electrochemical impedance analysis of a platinised $\mathrm{MgHf}_{4} \mathrm{P}_{6} \mathrm{O}_{24}$ solid-state electrolyte is presented in Fig. 6. The impedance analysis of $\mathrm{MgHf}_{4} \mathrm{P}_{6} \mathrm{O}_{24}$ solid-state electrolyte illustrated in Fig. 6 demonstrates the electrical properties of $\mathrm{Mg}^{2+}$-cation conducting specie in $\mathrm{MgHf}_{4} \mathrm{P}_{6} \mathrm{O}_{24}$ solid-state electrolyte. Fig. 6 further identifies the contribution from the grain interior, grain boundary and electrode-electrolyte interface in the high, intermediate and low frequency regions of the Nyquist plots for impedance analysis [9]. The impedance spectra measured in this study falls within the $182-747^{\circ} \mathrm{C}$ temperature and $100 \mathrm{mHz}-32 \mathrm{MHz}$ frequency range. In addition, the impedance spectra in Fig. 6(a) meanwhile shows a single slightly 
depressed semicircle at higher-frequency followed immediately by the low-frequency spike inclined at angle of $45^{\circ}$. The appearance of such an inclined spike at low-frequencies therefore demonstrates the measured sample $\mathrm{MgHf}_{4} \mathrm{P}_{6} \mathrm{O}_{24}$ as an ionic conductor similar to $\mathrm{MgZr}_{4} \mathrm{P}_{6} \mathrm{O}_{24}$ sample pellets $[10,11]$. The slightly depressed semicircle in Fig. 6 is attributed to the CPE parameter and it appears to suggest non-Debye type of relaxation behaviour [12] since the centre of the depressed semicircle is located below the axis, this electrochemical impedance behaviour is similar to those observed in other solid-state electrolytes [13]. Furthermore, real impedance, $\operatorname{ReZ}(\Omega)$ obtained from intersection of the semicircle at a lower frequency with the $\mathrm{x}$-axis, corresponds to the dc resistance. Also, the observed slightly depressed semicircle can result from the ionic migration in the bulk of solid-state electrolyte which is indicative of sintered sample pellets confirming the absence of grain boundary effects. Meanwhile, inclined spike in the low-frequency region may be attributed to the polarisation effect at the electrodeelectrolyte interface [14], which is similar to the outcome of $\mathrm{MgZr}_{4} \mathrm{P}_{6} \mathrm{O}_{24}$ impedance analysis [1]. The border frequency $\mathrm{f}_{\mathrm{b}}$ in Fig. 6 corresponds to $6.38 \mathrm{kHz}, 1.60 \mathrm{kHz}$ and $2.02 \mathrm{kHz}$ for the $\mathrm{MgHf}_{4} \mathrm{P}_{6} \mathrm{O}_{24}$ solid-state electrolyte at $273^{\circ} \mathrm{C}, 690^{\circ} \mathrm{C}$ and $747^{\circ} \mathrm{C}$, respectively.

Electric modulus in Fig. 6(a) and Fig. 6(b) was relied upon to illustrate relaxation dynamics of the ionic species. Further, variations of imaginary component $\left(\mathrm{M} " / \mathrm{C}_{\mathrm{o}}\right)$ as a function of frequency $(\omega)$ at different temperatures show clearly the resolved peaks at unique peak frequencies, with the peaks displaying a tendency to shift towards a higher frequency region with increase in temperature. This behaviour suggests a conduction mechanism which is a thermally activated type of correlated hopping of $\mathrm{Mg}^{2+}$-cations. Reproducibility mechanism is presented in Fig. 6(a) which shows no clear temperature profile deviation at $273-275^{\circ} \mathrm{C}$.

As impedance temperature increases from $273^{\circ} \mathrm{C}$ in Fig. 6 (a) to $690^{\circ} \mathrm{C}$ and then $747^{\circ} \mathrm{C}$ in Fig. 6 (b), the depressed bulk semicircle gradually becomes smaller and, the inclined spike on the electrode-electrolyte interface gradually bent downward to become a depressed semicircle, this implies that as the bulk resistance $\mathrm{R}_{\mathrm{b}}$ is decreasing the reversibility of charge migration at electrode-electrolyte interface is increasing [15]. Furthermore, the semicircles seen in Fig. 6(b) are not starting from the origin, implying there is a finite resistance $R_{s}$ representing a lumped electrode-electrolyte interfacial resistance in series with a parallel combination of $\mathrm{R}_{b}$ and $\mathrm{CPE}_{b}$ representing constant phase element, $\mathrm{CPE}$.

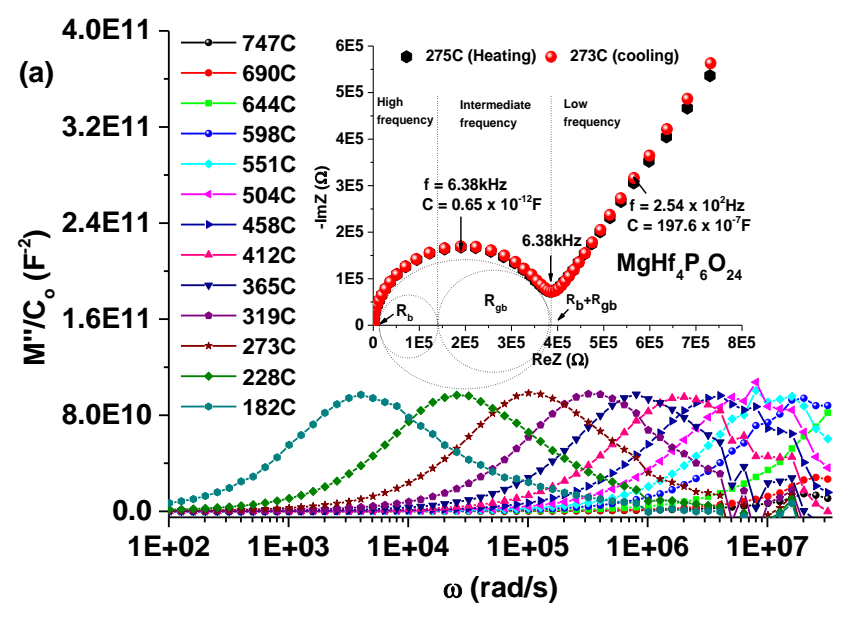




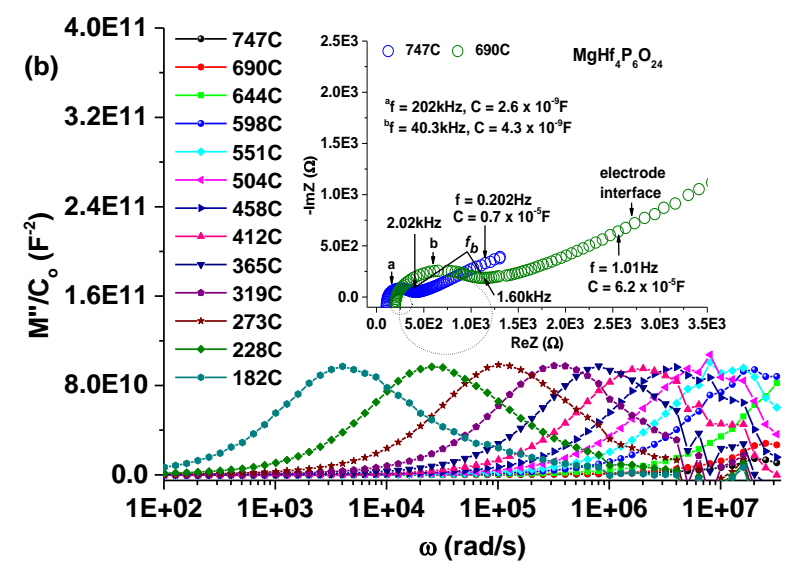

Figure 6. Nyquist plots and electric modulus of $\mathrm{MgHf}_{4} \mathrm{P}_{6} \mathrm{O}_{24}$ solid-state electrolyte at (a) 273$275^{\circ} \mathrm{C}$ (b) $690^{\circ} \mathrm{C}$ and $747^{\circ} \mathrm{C}$ temperatures in $100 \mathrm{mHz}-32 \mathrm{MHz}$ frequency range

The calculated value of the capacitance of the Nyquist plots of $\mathrm{MgHf}_{4} \mathrm{P}_{6} \mathrm{O}_{24}$ solid-state electrolyte at different temperatures using frequency at the maximum point of both semicircles in Fig. 6(a) and Fig. 6(b) is illustrated in Table 1:

In using the relationship, $\mathrm{C}=(2 \pi \mathrm{fR})^{-1}$ where $\mathrm{f}$ and $\mathrm{R}$ are considered the frequency and resistance of the electroceramic circuit;

\section{Table 1}

Capacitance values and their possible interpretation

\begin{tabular}{lllll}
\hline $\begin{array}{l}\text { Solid-State } \\
\text { Electrolyte }\end{array}$ & $\begin{array}{l}\text { Frequency } \\
(\mathrm{Hz})\end{array}$ & $\begin{array}{l}\text { Resistance } \\
(\Omega)\end{array}$ & $\begin{array}{l}\text { Capacitance } \\
(\mathrm{F})\end{array}$ & $\begin{array}{l}\text { Phenomenon } \\
\text { Responsible [10] }\end{array}$ \\
\hline $\begin{array}{l}\mathrm{MgHf}_{4} \mathrm{P}_{6} \mathrm{O}_{24} \\
\left(273^{\circ} \mathrm{C}\right)\end{array}$ & $6.38 \times 10^{3}$ & $3.85 \times 10^{5}$ & $0.65 \times 10^{-12}$ & bulk \\
$\begin{array}{l}45^{\circ} \text { electrode } \\
\text { spike }\end{array}$ & $2.54 \times 10^{2}$ & $3.17 \times 10^{5}$ & $197.6 \times 10^{-7}$ & $\begin{array}{l}\text { sample-electrode } \\
\text { interface }\end{array}$ \\
$\begin{array}{l}\mathrm{MgHf}_{4} \mathrm{P}_{6} \mathrm{O}_{24} \\
\left(690^{\circ} \mathrm{C}\right)\end{array}$ & $40.3 \times 10^{3}$ & $9.18 \times 10^{2}$ & $4300 \times 10^{-12}$ & bulk \\
$\begin{array}{l}45^{\circ} \text { electrode } \\
\text { spike }\end{array}$ & $0.101 \times 10^{1}$ & $2.54 \times 10^{3}$ & $6.2 \times 10^{-5}$ & sample-electrode \\
$\mathrm{MgHf}_{4} \mathrm{P}_{6} \mathrm{O}_{24}$ & $2.02 \times 10^{5}$ & $3.03 \times 10^{2}$ & $2600 \times 10^{-12}$ & $\begin{array}{l}\text { bulk } \\
\left(747^{\circ} \mathrm{C}\right)\end{array}$ \\
$\begin{array}{l}45^{\circ} \text { electrode } \\
\text { spike }\end{array}$ & $2.02 \times 10^{-1}$ & $11.47 \times 10^{2}$ & $0.7 \times 10^{-5}$ & $\begin{array}{l}\text { sample-electrode } \\
\text { interface }\end{array}$ \\
\hline
\end{tabular}




\section{Temperature dependence of ionic conductivity}

Fig. 7 describes the ionic conductivity of $\mathrm{MgHf}_{4} \mathrm{P}_{6} \mathrm{O}_{24}$ solid-state electrolyte as a function of temperature. In this analysis, the ionic conductivity of $\mathrm{MgHf}_{4} \mathrm{P}_{6} \mathrm{O}_{24}$ solid-state electrolyte was measured showing potential of being used interchangeably in structural and electrochemical applications. However, several details are outlined in Fig. 7; firstly, the linearity of the plots, which suggest there are no significant structural and phase changes noticed in the impedance temperature range. The activation energy, $E_{a}$ which includes the energy of the formation and migration of ions in the solid-state electrolytes were determined from the gradient of Arrhenius plots by fitting the ionic conductivity data with Arrhenius equation presented in Eq. 1 .

$\sigma \mathrm{T}=\sigma_{\mathrm{o}} \exp \left(-\frac{E_{a}}{k T}\right)$

where $\sigma_{\mathrm{o}}$ is pre-exponential factor related to the effective number of mobile charge carriers, $\mathrm{T}$ is the absolute temperature (in Kelvin, $\mathrm{K}$ ), $\mathrm{k}$ is the Boltzmann constant and $\mathrm{E}_{\mathrm{a}}$ is the thermal activation energy for oxide ion migration.

Ionic conduction has been found to be of thermally activated transport with different activation energy and ionic conductivity depending on the composition of electrolytes [16-18], which shows therefore, the ionic conductivity of samples in this study increases exponentially as the impedance temperatures increase. Moreso, the $\mathrm{MgHf}_{4} \mathrm{P}_{6} \mathrm{O}_{24}$ solid-state electrolytes therefore exhibits an ionic conductivity of $4.52 \times 10^{-4} \mathrm{Scm}^{-1}$ at $747^{\circ} \mathrm{C}$. Meanwhile, the bulk activation energy, $\mathrm{E}_{\mathrm{a}}$ of $\mathrm{MgHf}_{4} \mathrm{P}_{6} \mathrm{O}_{24}$ solid-state electrolyte shown in Figure 7 deduced from the slope of $\ln \sigma_{\mathrm{dc}} \mathrm{T}-1000 \mathrm{~T}^{-1}$ plots are $0.74 \pm 0.02 \mathrm{eV}$. The $\mathrm{E}_{\mathrm{a}}$ for $\mathrm{MgHf}_{4} \mathrm{P}_{6} \mathrm{O}_{24}$ solid-state electrolyte in this study therefore signifies greater mobility of $\mathrm{Mg}^{2+}$-cations, exhibiting an ionic conductivity at $747^{\circ} \mathrm{C}$ comparable with that earlier published [1]. In this study however, the conductivity data of $\mathrm{MgHf}_{4} \mathrm{P}_{6} \mathrm{O}_{24}$ solid-state electrolyte in Fig. 7 was measured between $182-747^{\circ} \mathrm{C}$ and remains chemically stable at higher temperatures compared to the $\mathrm{MgZr}_{4} \mathrm{P}_{6} \mathrm{O}_{24}$ solid-state electrolytes, which transforms at sintering temperatures greater than $1300^{\circ} \mathrm{C}[1]$.

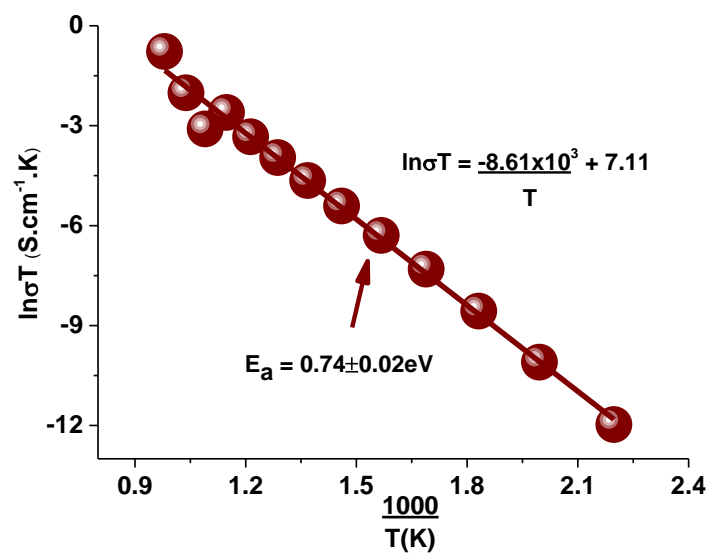

Figure 7. Ionic conductivity of $\mathrm{MgHf}_{4} \mathrm{P}_{6} \mathrm{O}_{24}$ solid-state electrolytes as a function of temperature 


\section{Principle of solid-state Mg-sensor}

The electrochemical cell of solid-state Mg-sensors fabricated in this study is shown in Eq. 2:

(+) air, $\mathrm{Fe}-\mathrm{Cr}, \mathrm{MgCr}_{2} \mathrm{O}_{4}+\mathrm{Cr}_{2} \mathrm{O}_{3}(\mathrm{~s}) / \mathrm{MgHf}_{4} \mathrm{P}_{6} \mathrm{O}_{24}(\mathrm{~s}) / \mathrm{Al}-\mathrm{Mg}(\mathrm{l})$, $\mathrm{Mo}(-)$

The measured open circuit voltage of solid-state $\mathrm{Mg}$-sensor at different $\mathrm{Mg}$ concentrations is presented in Eq. 3:

$\mathrm{E} / \mathrm{V}( \pm 0.003)=2.2013+0.0754 \log \mathrm{X}_{\mathrm{Mg}}$

The voltage generated across two dissimilar metal leads from the two electrodes is as shown; $[\mathrm{Mo}(+)-\mathrm{Fe}-\mathrm{Cr}(-)]$ at $700 \pm 5^{\circ} \mathrm{C}$ measured independently is $-0.0093 \mathrm{~V}$. Therefore, the voltage of the cell in Eq. 2, corrected for thermo-emf measurement in this study is presented in Eq. 4:

$\mathrm{E} / \mathrm{V}( \pm 0.003)=2.1920+0.0754 \log \mathrm{X}_{\mathrm{Mg}}$

\section{Analysis of solid-state Mg-sensor}

Fig. 8 shows the response of $\mathrm{Mg}$-sensor to changes in $\mathrm{Mg}$ concentration and its corresponding emf at a particular time, while holding the experimental temperature at $700 \pm 5^{\circ} \mathrm{C}$. It further shows that while adding $\mathrm{Mg}$-rod wrapped in $\mathrm{Al}$-foil to a pure liquid $\mathrm{Al}$ at different intervals, the linear pattern signal of the $\mathrm{Mg}$-sensor emf against the varied logarithmic composition of $\mathrm{Mg}$ demonstrates increasing emf of $\mathrm{Mg}$-sensor to increasing concentration of $\mathrm{Mg}$ samples in liquid Al. It was however observed in this study that the solid-state $\mathrm{Mg}$-sensor respond rapidly to $\mathrm{Mg}$ concentration on the first dipping, leading to fast equilibration at a shorter time which in most cases ensure an accurate amount of $\mathrm{Mg}$ concentration in the liquid $\mathrm{Al}$.

The response sequence of $\mathrm{Mg}$-sensor designed and fabricated using $\mathrm{MgZr}_{4} \mathrm{P}_{6} \mathrm{O}_{24}$ as solid-state electrolyte and biphasic powder mixture of $\mathrm{MgCr}_{2} \mathrm{O}_{4}+\mathrm{Cr}_{2} \mathrm{O}_{3}$ as reference electrode, varying the $\mathrm{Mg}$ concentration at $727 \pm 5^{\circ} \mathrm{C}$ has been published $[2,19]$. The response sequences of solidstate $\mathrm{Mg}$-sensor fabricated using $\mathrm{MgHf}_{4} \mathrm{P}_{6} \mathrm{O}_{24}$ solid-state electrolyte in this study as presented in Fig. 7(a) shows the sensor emf increased to $1.92 \mathrm{~V}$ with the addition of 0.005 wt. $\% \mathrm{Mg}$ composition after the initial calibration and equilibration at a zero baseline. The addition of a further $0.05 \mathrm{wt} . \% \mathrm{Mg}$ composition depicting an increment of about $40 \mathrm{mV}$ to achieve $1.96 \mathrm{~V}$ after equilibration for $0.5 \mathrm{~h}$. Furthermore, sensor emf of $2.09 \mathrm{~V}$ was achieved after the concentration was increased by a further addition of $0.5 \mathrm{wt} . \% \mathrm{Mg}$. The sensor emf then shows unstable progression with the addition of 1.0 and $1.5 \mathrm{wt} . \% \mathrm{Mg}$, with a stable emf progression of $2.10 \mathrm{~V}$, respectively. It therefore shows in this analysis that a voltage proportional to the logarithm of the Mg concentration with appropriate sensitivity was attained. However, it is 
clear that the solid-state $\mathrm{Mg}$-sensor designed, fabricated and analysed in this study expresses a reasonable sensitivity sequence of the solid-state $\mathrm{Mg}$-sensor which shows in the increasing voltage outlined in Fig. 7
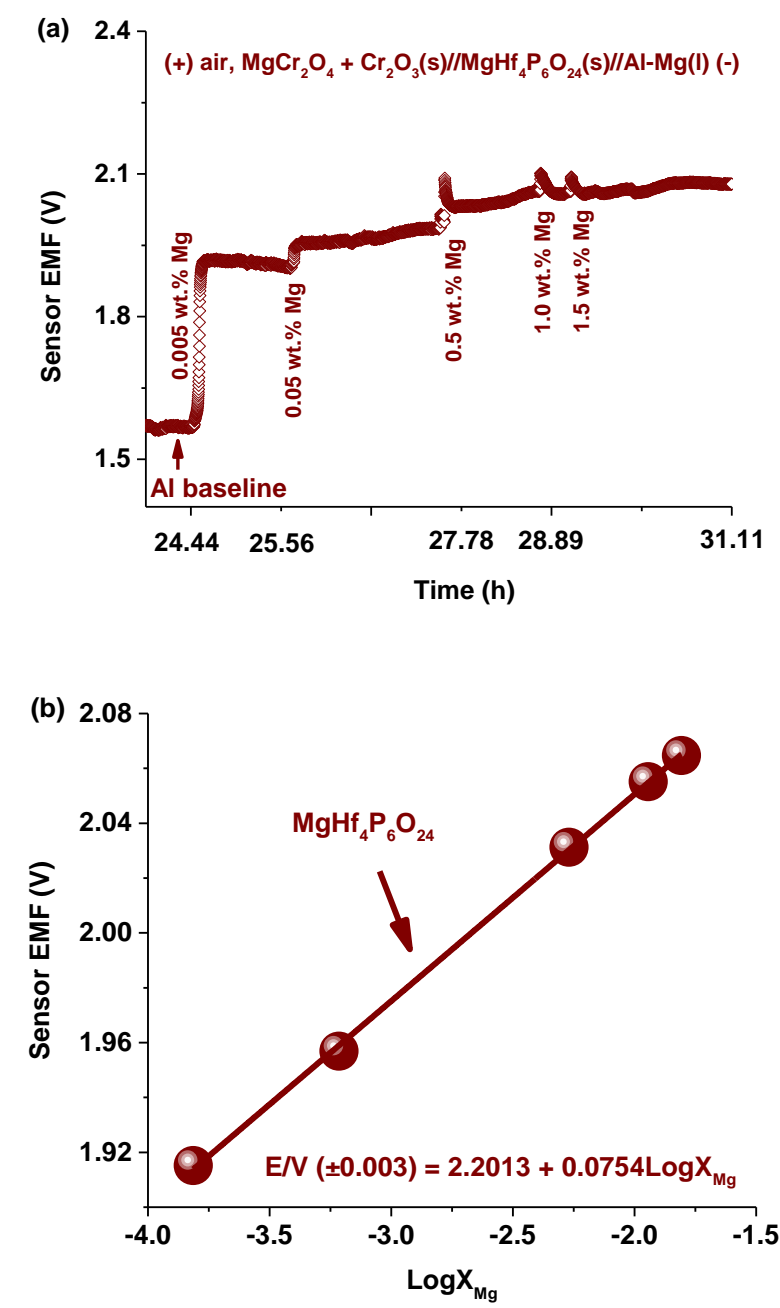

Figure 7. $\mathrm{Mg}$-sensor response as a function of $\mathrm{Mg}$ concentration in molten $\mathrm{Al}$ at $700 \pm 5^{\circ} \mathrm{C}$, using (a) $\mathrm{MgHf}_{4} \mathrm{P}_{6} \mathrm{O}_{24}$ solid-state electrolytes and biphasic mixture of $\mathrm{MgCr}_{2} \mathrm{O}_{4}+\mathrm{Cr}_{2} \mathrm{O}_{3}$ reference electrode in $\mathrm{Mg}$-sensor fabrication, and (b) corresponding $\mathrm{Mg}$-sensor emf variation using $\mathrm{MgHf}_{4} \mathrm{P}_{6} \mathrm{O}_{24}$ solid-state electrolyte.

\section{Transport number of $\mathrm{Mg}^{2+}$-cation in $\mathrm{MgHf}_{4} \mathrm{P}_{6} \mathrm{O}_{24}$ solid-state electrolyte}

It is evident that during solid-state $\mathrm{Mg}$-sensor testing in molten $\mathrm{Al}$ alloys, the activity of $\mathrm{Mg}$ is relatively high at the alloy electrode and very low at the ceramic electrode exposed to air.

The electrochemical reaction at the alloy electrode on the right-hand side of the cell is:

$$
\{\mathrm{Mg}\}_{\mathrm{Al}(\mathrm{l})} \rightarrow \mathrm{Mg}^{2+}+2 \mathrm{e}^{-}
$$


whereas, the electrochemical reaction at the reference electrode on the left-hand side is:

$\mathrm{Mg}^{2+}+0.5 \mathrm{O}_{2}(\mathrm{~g})+\mathrm{Cr}_{2} \mathrm{O}_{3}$ (cor) $+2 \mathrm{e}^{-} \rightarrow \mathrm{MgCr}_{2} \mathrm{O}_{4}(\mathrm{sp})$

EMF (E/V) of the solid-state Mg-sensor defined in this study is presented as Eq. 7:

$\mathrm{E}(\mathrm{V})=-\frac{1}{n F} \int_{\mu_{M g}^{i i}}^{\mu_{M g}^{i}} t_{i o n} d \mu_{M g}$

where $\mathrm{F}=$ Faraday constant in Coulombs $\mathrm{mol}^{-1}, \mathrm{n}=2$ is the number of electrons participating in the electrode reactions, $\mathrm{t}_{\text {ion }}=$ transport number of the conducting species $\left(\mathrm{Mg}^{2+}\right)$, and $\mu_{\mathrm{Mg}}=$ chemical potential of $\mathrm{Mg}$ defined as RTlna $\mathrm{Mg}_{\mathrm{g}}$ where $\mathrm{a}_{\mathrm{Mg}}=$ thermodynamic activity of $\mathrm{Mg}$, the neutral form of the conducting species in the electrolyte. It is apparent from the polarity of the cell and emf response of the $\mathrm{Mg}$-sensor that, the chemical potential of $\mathrm{Mg}$ at the reference electrode $\left(\mu_{\mathrm{Mg}}^{\mathrm{ii}}\right)$ is lower than that at the molten alloy sensing electrode $\left(\mu_{\mathrm{Mg}}^{\mathrm{i}}\right)$.

Assuming $\mathrm{t}_{\mathrm{Mg} 2+}$ in $\mathrm{MgHf}_{4} \mathrm{P}_{6} \mathrm{O}_{24}$ is $\geq 0.99$, emf of solid-state $\mathrm{Mg}$-sensor can be calculated using thermodynamic activity of $\mathrm{Mg}$ in molten $\mathrm{Al}$. The Gibbs energy of formation of $\mathrm{MgCr}_{2} \mathrm{O}_{4}(\mathrm{sp})$ from its component binary oxides according to Jacob [20] is presented in Eq. 8 and Eq. 9:

$$
\begin{aligned}
& \mathrm{MgO}(\mathrm{rs})+\mathrm{Cr}_{2} \mathrm{O}_{3}(\text { cor })=\mathrm{MgCr}_{2} \mathrm{O}_{4}(\mathrm{sp}) \\
& \Delta \mathrm{G}_{\mathrm{f}(\mathrm{ox})}^{\mathrm{o}}( \pm 400) / \mathrm{Jmol}^{-1}=-45,200+5.36(\mathrm{~T} / \mathrm{K})
\end{aligned}
$$

At $700^{\circ} \mathrm{C}(973 \mathrm{~K}) ; \Delta \mathrm{G}^{\mathrm{o}}=-39985 \mathrm{Jmol}^{-1}$.

By combining this with the Gibbs energy of formation of $\mathrm{MgO}$ at the same temperature

$$
\mathrm{Mg}(\mathrm{l})+0.5 \mathrm{O}_{2}(\mathrm{~g})=\mathrm{MgO}(\mathrm{s}), \Delta \mathrm{G}_{\mathrm{f}}^{\mathrm{o}}=-501401 \mathrm{Jmol}^{-1}
$$

The Gibbs energy change associated with the virtual cell reaction at $700^{\circ} \mathrm{C}$ is given by;

$$
\mathrm{Mg}(\mathrm{l})+\mathrm{Cr}_{2} \mathrm{O}_{3}(\text { cor })+0.5 \mathrm{O}_{2}(\mathrm{~g})=\mathrm{MgCr}_{2} \mathrm{O}_{4}(\mathrm{sp}), \Delta \mathrm{G}^{\mathrm{o}}=-541386 \mathrm{Jmol}^{-1}
$$

The estimated uncertainty in the value of Gibbs energy change for reaction (11) is $5 \mathrm{Jmol}^{-1}$. EMF of the Mg-sensor is related to the activity of $\mathrm{Mg}$ in molten $\mathrm{Al}$ by the relation;

$-2 \mathrm{FE}=\Delta \mathrm{G}=\Delta \mathrm{G}^{\mathrm{o}}+\mathrm{RT} \ln \mathrm{a}_{\mathrm{Mg}}+0.5 \mathrm{RT} \ln _{\mathrm{O} 2}$ 
Thus, the theoretical emf of the sensor at $700^{\circ} \mathrm{C}$ can be calculated as;

$\mathrm{E}_{\mathrm{th}}( \pm 0.026) / \mathrm{V}=2.7728+0.09653 \log \mathrm{a}_{\mathrm{Mg}}$

Aghdam and Soltanieh [21] measured the activity of $\mathrm{Mg}$ in molten $\mathrm{Al}$ using electrochemical cell with the eutectic mixture of $\mathrm{MgCl}_{2}-\mathrm{CaCl}_{2}$ as an electrolyte in a temperature range from 700 to $800^{\circ} \mathrm{C}$ and $\mathrm{Mg}$ composition from 0.07 to 12.1 . The activity coefficient of $\mathrm{Mg}$ at $700^{\circ} \mathrm{C}$ for dilute alloys up to 1.4 atom $\% \mathrm{Mg}$ can be expressed by the relation,

$\log \gamma_{M g}=-0.7624+23.183 X_{M g}$

Expressing the activity of $\mathrm{Mg}$ in Eq. 13 as a product of mole fraction and activity coefficient, one obtains;

$\mathrm{E}_{\mathrm{th}}( \pm 0.03) / \mathrm{V}=2.6992+2.2379 \mathrm{X}_{\mathrm{Mg}}+0.09653 \log \mathrm{X}_{\mathrm{Mg}}$

Fig. 8(a) shows the compared theoretical and measured emf, whereas, the average transport number is shown in Fig. 8(b). On the average however, the measured emf values are lower by $\sim 0.359 \pm 0.022 \mathrm{~V}$. The average transport number at $700 \pm 5^{\circ} \mathrm{C}$ for $\mathrm{Mg}^{2+}$-cations in $\mathrm{MgHf}_{4} \mathrm{P}_{6} \mathrm{O}_{24}$ solid-state electrolyte over the range of chemical potential at the two electrodes are computed using the difference between experimental and theoretical emfs assuming that the electrodes are not polarised.

$t_{M g^{2+}}=\frac{E_{\text {exp }}}{E_{t h}}$

The average transport number for $\mathrm{Mg}^{2+}$-cations in $\mathrm{MgHf}_{4} \mathrm{P}_{6} \mathrm{O}_{24}$ solid electrolyte as a function of $\mathrm{Mg}$ concentration is $0.84 \pm 0.03$ shown in Fig. 8 (b).

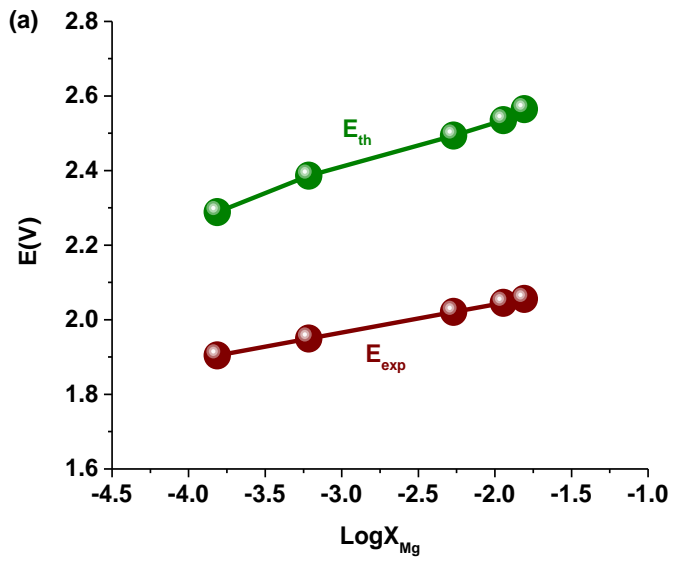




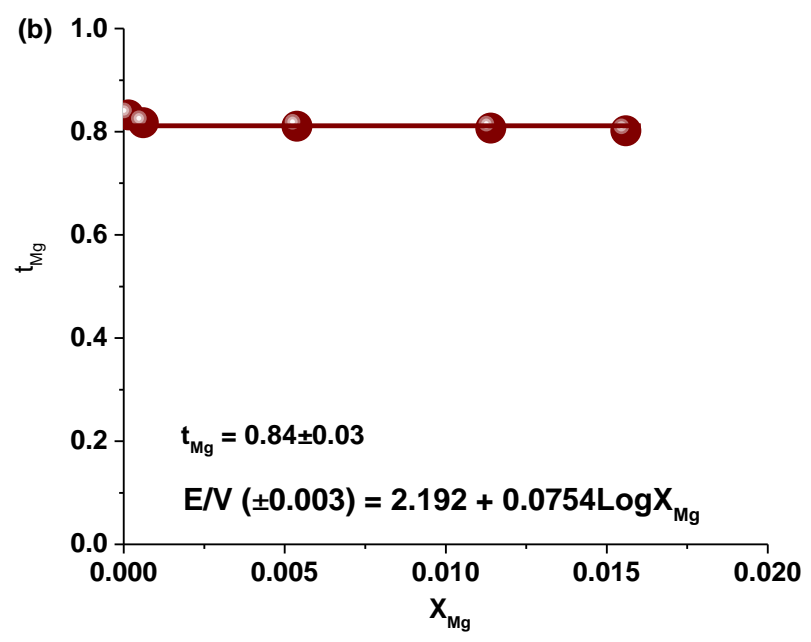

Figure 8. The (a) relationship between measured emf of the Mg-sensor with the theoretical emf, and (b) variation of the average transport number of $\mathrm{Mg}^{2+}$-cations in $\mathrm{MgHf}_{4} \mathrm{P}_{6} \mathrm{O}_{24}$ at $700 \pm 5^{\circ} \mathrm{C}$.

\section{Conclusion}

Based on TGA-DSC profiles, dried powders of $\mathrm{MgHf}_{4} \mathrm{P}_{6} \mathrm{O}_{24}$ xerogels were calcined at $900^{\circ} \mathrm{C}$ to produce a single phase nanopowder of definite crystallinity. X-ray diffraction (xrd) further confirmed the formation of single phase nanopowders and pellets calcined and sintered at $900^{\circ} \mathrm{C} \leq \mathrm{T} /{ }^{\circ} \mathrm{C} \leq 1300$. However, $\mathrm{MgHf}_{4} \mathrm{P}_{6} \mathrm{O}_{24}$ solid-state electrolyte remain chemically stable at high-temperatures. Ionic conductivity of the novel $\mathrm{MgHf}_{4} \mathrm{P}_{6} \mathrm{O}_{24}$ solid-state electrolyte is measured, characterised and reported for the first time in this study. The characterised solidstate electrolytes meanwhile attained stability in liquid $\mathrm{Al}$ at $700 \pm 5^{\circ} \mathrm{C}$ and were successfully used in the design and fabrication of high-temperature solid-state $\mathrm{Mg}$-sensors for sensing $\mathrm{Mg}$ at varying concentration in molten $\mathrm{Al}$.

\section{Authors' information}

*Email: mohammed.adamu@aol.com; Tel: 0044(0)7459749136

\section{Orcid}

Girish M Kale https://orcid.org/0000-0002-3021-5905

Mohammed Adamu https://orcid.org/0000-0002-5028-9370

\section{Funding}

The authors declare no competing financial interest. 


\section{Acknowledgements}

The authors acknowledged the Tertiary Education Trust Fund (TETFund) for funding the PhD research student and the School of Chemical and Process Engineering, University of Leeds for the world class research infrastructure provided in support of this study.

\section{References}

(1) M. Adamu, K.T. Jacob, G.M. Kale, Assessment of $\mathrm{MgZr}_{4} \mathrm{P}_{6} \mathrm{O}_{24}$ as a Solid Electrolyte for Sensing Mg in Molten Non-Ferrous Alloys. J. Electrochem. Soc. 167(2) (2020) 027532.

(2) G.M. Kale, L. Wang, Y. Hong, High-Temperature Sensor for In-Line Monitoring of Mg and $\mathrm{Li}$ in Liquid $\mathrm{Al}$ Employing Ion-Conducting Ceramic Electrolytes. Int. J. Appl. Ceram. Technol. 1(2) (2004) 180-187.

(3) J.W. Fergus, Electrochemical sensors: Fundamentals, Key Materials, and Applications. Solid State Electrochemistry I: Fundamentals, Materials and their Applications. (2009) 427491.

(4) V.I. Pet'kov, A.S. Shipilov, A.V. Markin, N.N. Smirnova, Thermodynamic Properties of Crystalline Magnesium Zirconium Phosphate. J. Therm. Anal. Calorim. 115(2) (2014) 14531463.

(5) G.M. Kale, K.T. Jacob, Thermodynamic Partial Properties of $\mathrm{Na}_{2} \mathrm{O}$ in Nasicon Solid Solution, $\mathrm{Na}_{1+\mathrm{x}} \mathrm{Zr}_{2} \mathrm{Si}_{\mathrm{x}} \mathrm{P}_{3-\mathrm{x}} \mathrm{O}_{12}$. J. Mater. Res. 4(2) (1989) 417-422.

(6) G.M. Kale, A.J. Davidson, D.J. Fray, Investigation into an Improved Design of $\mathrm{CO}_{2}$ Sensor. Solid State Ionics. 86-88 (1996), 1107-1110.

(7) S. Mudenda, G.M. Kale, Electrochemical Determination of Activity of $\mathrm{Na}_{2} \mathrm{O}$ in $\mathrm{Na}_{2} \mathrm{Ti}_{6} \mathrm{O}_{13^{-}}$ $\mathrm{TiO}_{2}$ Two Phase System between 803-1000 K. Electrochimica Acta. 258 (2017) 1059-1063.

(8) M. Kakihana, Invited Review "Sol-Gel" Preparation of High Temperature Superconducting Oxides. J. Sol-Gel Sci Technol. 6(1) (1996) 7-55.

(9) J. Bauerle, Study of solid electrolyte polarization by a complex admittance method. $J$. Phys. Chem. Solids. 30(12) (1969) 2657-2670.

(10) J.T. Irvine, D.C. Sinclair, A.R. West, Electroceramics: characterisation by impedance spectroscopy. Adv. Mater. 2(3) (1990) 132-138.

(11) R.A. Huggins, Simple method to determine electronic and ionic components of the conductivity in mixed conductors a review. Ionics. 8(3-4) (2002) 300-313.

(12) J.R. MacDonald, "Impedance Spectroscopy-Emphasising Solid Materials and Synthesis," In: J.R. Macdonald, Ed., Theory, John Wiley and Sons Inc., New York, 1987, pp. 13, 77.

(13) B.V.R. Chowdari, R. Gopalakrishnan, Impedance and modulus spectroscopy of vitreous AgI- $\mathrm{Ag}_{2} \mathrm{O}-\mathrm{P}_{2} \mathrm{O}_{5}$ system. Solid State Ionics. 18 (1986) 483-487.

(14) P. Ferloni, A. Magistris, New materials for solid state electrochemistry. J. Phys. IV France, 4 (1994) C1-3-C1-15.

(15) Q.B. Bo, G.X. Sun, J. Meng, Preparation, structure and oxide ion conductivity in $\mathrm{Ce}_{6-}$ ${ }_{x} \mathrm{Y}_{\mathrm{x}} \mathrm{MoO}_{15-\delta}(\mathrm{x}=0.1-1.4)$ solid solutions. J. Phys. Chem. Solids. 67(4) (2006) 732-737. 
(16) M.G. Bellino, D.G. Lamas, N.E. Walsoe de Reca, A Mechanism for the Fast Ionic Transport in Nanostructured Oxide-Ion Solid Electrolyte. Adv. Mater. 18(22) (2006) 30053009 .

(17) M. Prabu, S. Selvasekarapandian, A.R. Kulkarni, S. Karthikeyan, G. Hirankumar, C. Sanjeeviraja, Ionic Transport Properties of $\mathrm{LiCoPO}_{4}$ Cathode Material. Solid State Ionics. 13(9) (2011) 1714-1718.

(18) A. Zuttel, Materials for hydrogen storage. Mater. Today. 6(9) (2003) 24-33.

(19) G.M. Kale, K.T. Jacob, L. Wang, Y. Hong, Solid-State Electrochemical Sensor For Monitoring Mg in Al Refining Process. ECS Trans. 1(13) (2006) 1-11.

(20) K.T. Jacob, Potentiometric determination of the Gibbs free energy of formation of cadmium and magnesium chromites. J. Electrochem. Soc. 124(12) (1977) 1827-1831.

(21) G.R.K. Aghdam, M. Soltanieh, Study of the Thermodynamic Properties of the Al-Mg Binary System Between 973-1073 K by the EMF Method. Can. Metall. Quart. 49(1) (2010) $39-45$.

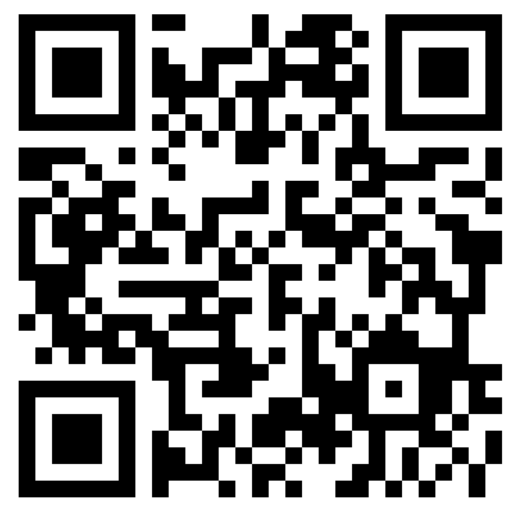

